\title{
PADDY DRYING IN MIXED ADSORPTION DRYER WITH ZEOLITE: DRYING RATE AND TIME ESTIMATION
}

\author{
Mohamad Djaeni $^{\left.{ }^{*}\right)}$, Dewi Ayuningtyas ${ }^{2)}$, Nurul Asiah ${ }^{2)}$, Hargono $^{1)}$, Ratnawati ${ }^{1)}$, \\ Jumali $^{3 a)}$, and Wiratno ${ }^{3 b)}$ \\ ${ }^{1)}$ Department of Chemical Engineering, Faculty of Engineering, Diponegoro University \\ Jl Prof. Soedharto, SH, Tembalang Semarang, Indonesia 50274 \\ Phone: 024) 7460058. Facs. (024)76480675 \\ ${ }^{2)}$ Student of Magister Study Program on Chemical Engineering \\ Department of Chemical Engineering; Faculty of Engineering; Diponegoro University \\ Jl Prof H. Soedharto, SH, Tembalang Semarang, Indonesia 50274 \\ Phone: 024) 7460058. Facs. (024)76480675 \\ ${ }^{3 a, b)}$ Agriculture Research and Development Agency \\ Ministry of Agriculture, Indonesia \\ Jl. Ragunan 29, Pasar Minggu, Jakarta 12540, Indonesia \\ Phone: (021)7806202; Facs. (021)7800644 \\ ${ }^{3 b)}$ South Sumatera Division \\ ${ }^{*}$ Corresponding author: m.djaeni@undip.ac.id
}

\begin{abstract}
Recently, the main problem of the rice stock and distribution in Indonesia is the quality degradation as indicated in unpleasant odor (smelly), stained, yellowness, and high percentage of broken rice. This is due to the low of paddy quality dried by from either direct sunlight or conventional fluidized bed dryer. As a result, the paddy cracks and breaks easily during milling in which causes the storage life being shorter as the enzymatic degradation by germ or fungi occurs. Air dehumidified with zeolite at drying medium temperature is potential to improve the quality of paddy. Zeolite is a material having high affinity to water vapor. In this case, the paddy and zeolite was mixed and fluidized with the air. The air will evaporate water from paddy, and at same time, the zeolite will adsorb water from air. Hence, the humidity of dryer can be kept low in which improves the driving force for drying. This work discusses the effect of presence of zeolite in the dryer, operational drying temperature, air velocity and relative humidity on drying rate of paddy. The results showed that increasing of zeolite as well as operational temperature increased the drying rate. In addition, using the model, the air dehumidification with zeolite and increase of air velocity can speed up drying time significantly at operational temperature below $80^{\circ} \mathrm{C}$. This condition is very suitable for paddy drying since the quality degradation can be avoided.
\end{abstract}

Keywords: adsorption; driving force; relative humidity

\begin{abstract}
Abstrak
PENGERINGAN PADI MENGGUNAKAN MIXED ADSORPTION DRYER DENGAN ZEOLITE: PERHITUNGAN LAJU DAN WAKTU PENGERINGAN. Saat ini, masalah utama dalam penyediaan dan distribusi beras Indonesia adalah penurunan kualitas yang ditunjukkan dari bau tidak sedap, banyak menir, menguning, dan bulir patah. Hal ini disebabkan oleh rendahnya kualitas gabah hasil pengeringan baik matahari ataupun konvensional dengan pemanas buatan. Akibatnya, banyak putir patah dan pecah saat penggilingan yang akan mendorong cepatnya aktifitas enzim, jamur, dan mikroorganisme. Udara yang didehumidifkasi zeolite pada temperature medium merupakan opsi potensial untuk meningkatkan kualitas gabah pada proses pengeringan. Zeolite merupakan adsorbent yang dapat digunakan untuk menurunkan kelembaban udara sehingga memungkinkan proses pengeringan pada suhu medium. Pada penelitian ini zeolite dan padi dicampur serta difluidisasi dengan udara pada berbagai suhu dan kecepatan. Udara akan menguapkan air dari padi dan pada saat yang sama, zeolite akan menyerap air dari udara. Sehingga kelembaban udara dalam pengering tetap rendah yang akan meningkatkan driving force pengeringan. Pada peneilitian ini dipelajari pengaruh jumlah zeolite dalam unggun, suhu, kelembaban dan kecepatan udara terhadap laju dan waktu pengeringan. Hasil menunjukkan bahwa penambahan zeolite, kenaikan suhu dan kecepatan udara akan menaikan laju pengeringan. Sementara penurunan kelembaban relatif udara akan
\end{abstract}


memperbesar laju pengeringan pada suhu operasi di bawah $80^{\circ} \mathrm{C}$. Kondisi ini sangat sesuai untuk padi sehingga penurunan kualitas dapat dihindari.

Kata kunci: adsorpsi; gaya tekan; relative humidity

\section{INTRODUCTION}

In many several countries, rice is still one of the major economic crops for consuming and producing. The most problems in rice stock and distribution is the quality degradation as indicated in unpleasant odor, broken, stained, and yellowness. This is due to the low of paddy quality dried by from either direct sunlight or conventional fluidized bed dryer. As a result, the paddy cracks and breaks easily during milling in which causes the storage life being shorter as the enzymatic degradation by germ or fungi occurs (Chrastil, 1994; Barber, 1972; FAO, 2002).

Currently, paddy has been dried in two methods namely direct sunlight dryer and fluidized bed dryer with conventional heating.

Direct sunlight dryer is simple and doesn't need fuel fossil for energy generation, but the system needs a large drying area, long drying time (often 3-5 days), high operational cost for labor, and depends highly on the climate both quality and sustainability (Djaeni et al., 2009). For example, in the dry season with high intensity of sunlight, the drying can be performed in 1-2 days resulting moisture content 12$14 \%$ in which is suitable for milling. In contrast, at the wet season, paddy drying needs 3-4 days with moisture content higher than $15 \%$. With this property, the paddy will break or damage easily during the milling. Moreover, the product will be quickly germinated that deteriorates and degrades the nutrition (Chrastil, 1994; Barber, 1972; FAO, 2002).

The other drawbacks of sunlight dryer are: damage by insects, rodents, birds, and animals, exposure to dew, wind, rain and storms, contamination by dirt, dust, wind-blown debris, and environmental pollution, and non-uniform drying process (Prakash, 2011; Djaeni, 2008).

Conventional dryer such fluidized bed is more attractive than sun drying because of the shorter operational time, low product contamination, lower operational costs, no dependency on the climate, and relative limited space usage (Prakash 2011; Ratti, 2001; Djaeni, 2008; Kiranoudis et al., 1996). However, the system operates in temperature upper $90^{\circ} \mathrm{C}$ which reduces the paddy quality (Wiset et al., 2001). The process also deals with in-efficient energy consumption.

Considering the paddy quality, energy efficiency as well as drying time, it is a challenge to find out the dryer that can work in low or medium temperature effectively and quickly. Air dehumidification by adsorbent such as silica, alumina, pillared clay, and rice husk, is an option to enhance the paddy drying efficiency as well as product quality (Witinantakit et al., 2006; Nagaya et al., 2006; Alikhan et al., 1992; Revila et al., 2006; Djaeni et al., 2009).

The zeolite is an alumino-silicate compound with tetrahedral bound linked by oxygen that has high affinity to the water. By activation using $\mathrm{KOH}$ or $\mathrm{NaOH}$, the adsorbing capacity can be enhanced up to 0.15-0.20 g water/g zeolite (Djaeni et al., 2012). With this material, the air can be dehumidified by adsorbing vapor while the air temperature increases at the same time due to the release of the adsorption heat. As a result, the air contains more sensible heat for drying which improves the total energy efficiency as well as retaining the product quality (Revila et al., 2006; Djaeni et al., 2009).

This paper discusses the performance of paddy drying with zeolite. In this study, the zeolite and paddy were mixed at different percentage in a column. The mixture was then fluidized by air as drying medium at various velocity and temperature. The air will evaporate water from the product, and at the same time, zeolite will adsorb vapor from air. As consequence, the air humidity can be kept low. Moreover, operational temperature can be maintained at the certain condition due to the latent heat of adsorption. So, the driving force of drying can be kept high.

\section{MATERIAL AND METHODS Experimental Set Up}

The drying processes were performed in a fluidized bed dryer equipped with blower to supply the air (see Figure 1). For initial, the air flow was set at $3 \mathrm{~m} \cdot \mathrm{s}^{-1}$ (minimum for fluidization). The process was then repeated for the others air velocity 3 and 5 $\mathrm{m} . \mathrm{s}^{-1}$, respectively. The air velocity was measured with an Extech Instruments Thermo-Anemometer 407113. While, the temperature and humidity of ambient air and air leaving the dryer were measured by Temperature and Humidity Meter KW0600561 Krisbow ${ }^{\circledR}$, Indonesia. The air temperature entering the dryer was measured by K-Type Thermocouple.

Ambient air with relative humidity (RH) between $70-80 \%$ and temperature between $29-33^{\circ} \mathrm{C}$ was heated in the heater completed with PID controller to reach dryer temperature (suppose $40^{\circ} \mathrm{C}$ for first experiment). The warm air passed the dyer containing the mixture of paddy and zeolite $3 \mathrm{~A}$ (provided by Zeochem, Switzerland). The weight of mixture is adjusted at 200 grams with the zeolite $20 \%$ (for first experiment).

The water content in paddy was measured every 10 minutes using Krisbow KW06-404 Grain Moisture Meter. The process was operated until 
moisture content in paddy close to $14 \%$ (wet basis). The process was repeated for the inlet air dryer temperature 50 and $60^{\circ} \mathrm{C}$, and the percentage of zeolite in the dryer $40 \%$ and $0 \%$ (without zeolite). The data in the form of moisture content in paddy versus time was plotted in graph to calculate the effective moisture diffusivity and the constant of drying rate.

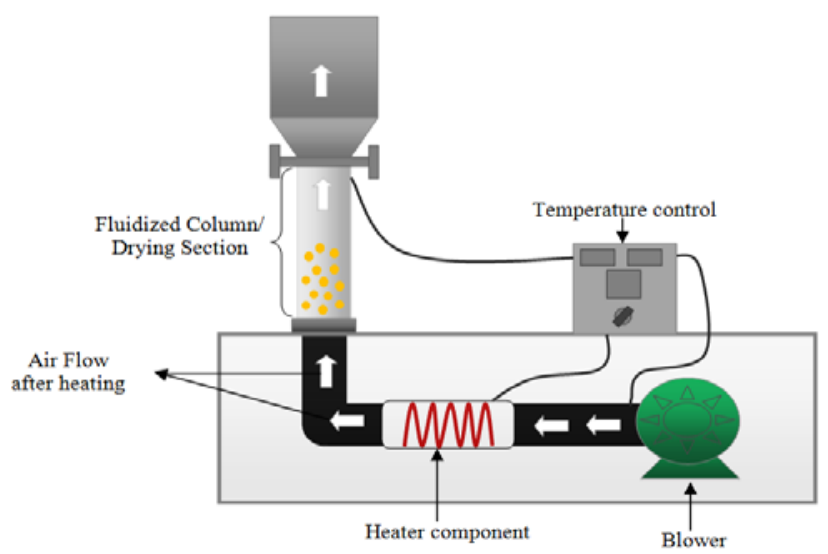

Figure1. Schematic overview of fluidized bed dryer

\section{Estimating Drying Rate Constant}

The simple mathematical model was used to estimate the moisture diffusivity. The model was derived based on the following assumptions:

- The shape of paddy was a cylinder with the 10 mm height and $3 \mathrm{~mm}$ diameter

- Pressure drop over the fluidized column was neglected

- The flow and temperature of air can be kept at desired value

- $\quad$ The fluidized bed paddy drying was a well mixed system

- The water and heat transport between zeolite and product particles take place through the air and not by particle contact

- Equilibrium moisture in paddy at various condition refers to the GAB equation cited from Iguaz and Virseda (2011)

Using observed moisture content in paddy versus time, the moisture diffusivity was estimated using the equation derived by Boudhrioua et al., (2003).

$$
\ln \left(\frac{\mathrm{Me}-\mathrm{M}}{\mathrm{M}_{\mathrm{e}}-\mathrm{M}_{\mathrm{o}}}\right)=\ln \left(\frac{8}{\pi^{2}}\right)-\frac{\pi^{2} \mathrm{Dt}}{\mathrm{I}^{2}}
$$

Where $\mathrm{t}$ is sampling time (s), $\mathrm{l}$ the size of paddy (m), $\mathrm{M}$ is the moisture in paddy at sampling time ( $\mathrm{kg}$ water/kg dry paddy), $\mathrm{M}_{\mathrm{e}}$ is the moisture loaded in paddy at equilibrium ( $\mathrm{kg}$ water/kg dry paddy), and $\mathrm{M}_{0}$ is the initial moisture in paddy (kg water/kg dry paddy).

The equilibrium moisture content for paddy $\left(\mathrm{M}_{\mathrm{e}}\right)$ is given by modified GAB model that incorporates the relationship between the equilibrium moisture content and the equilibrium relative humidity (Iguaz and Virseda, 2011). GAB equation used to model equilibrium moisture content for paddy $\left(\mathrm{M}_{\mathrm{e}}\right)$ is expressed as:

$$
\left(M_{e}\right)=\frac{\text { A.B }\left(\frac{C}{T}\right) \cdot a_{w}}{\left(1-B \cdot a_{w}\right)\left[1-B \cdot a_{w}+\left(\frac{C}{T}\right) \cdot B \cdot a_{w}\right]}
$$

The GAB constant for the paddy are $\mathrm{A}=12,752 ; \mathrm{B}=0,507$; and $\mathrm{C}=220,039 ; a_{w}$ is the water activity which is assumed to be equal to the relative humidity $(R H)$. These values are relatively same for all kind of paddy.

The drying rate constant can be estimated based on Sherwood number (Sh) as follow:

$$
\mathrm{k}=\frac{\mathrm{Sh} \cdot \mathrm{D}}{\mathrm{l}}
$$

Here, $\mathrm{k}$ is drying rate constant $\left(\mathrm{m} . \mathrm{s}^{-1}\right)$, and $\mathrm{D}$ is the diffusivity of moisture in paddy $\left(\mathrm{m}^{2} \cdot \mathrm{s}^{-1}\right)$.

The Sherwood number for paddy and air system in fluidized bed dryer is a function of Reynold and Schmidt number referring to the following equation (Prakash, 2011).

$$
\mathrm{Sh}=2+0.522 \mathrm{Re}^{0.5} \mathrm{Sc}^{0.33}
$$

With the $\mathrm{k}$ value, the response of moisture in paddy versus time can modeled (see equation 5 and 6). With these formulations, the drying time for paddy can be estimated for various temperature, relative humidity and air velocity.

$$
\begin{aligned}
\frac{\delta \mathrm{M}}{\delta \mathrm{t}} & =-\mathrm{k}\left(\mathrm{M}-\mathrm{M}_{\mathrm{e}}\right) \\
\mathrm{t}_{\mathrm{d}} & =\frac{1}{\mathrm{k}} \ln \left(\frac{\mathrm{Mo}-\mathrm{Me}}{\mathrm{M}-\mathrm{Me}}\right)
\end{aligned}
$$

Where, $t_{d}$ is the drying time (s).

\section{RESULT AND DISCUSSION}

This section presents and discusses the effect of drying condition on the constant of drying rate and drying time. Firstly, the moisture content in paddy versus time was observed by performing experiment at different percentage of zeolite and operational temperature. Secondly, the data was used for estimating moisture diffusivity and drying rate constant as formulated in Equation 1-5. Lastly, with the constant of drying rate, the drying time at extrapolated condition were also predicted.

\section{The Effect of Zeolite Percentage}

The two different percentages of zeolite in the fluidized bed dryer (20\% and $40 \%$ ) were compared with the paddy drying without zeolite at operational temperature $50^{\circ} \mathrm{C}$. As a response, the moisture content versus time was observed and plotted in graph as illustrated in Figure 2.

The zeolite adsorbs water from the air during the drying process. Hence, the humidity of air can be kept low. As a result, the driving force of drying is higher as indicated in the decrease of moisture content in paddy. As shown in Fig. 2, the zeolite gave positive effect on paddy drying significantly. The paddy drying with zeolite resulted lower moisture 
content. It indicated that much water was removed from the paddy (Revila et al., 2006; Djaeni et al., 2012; and Witinantakit et al., 2006).

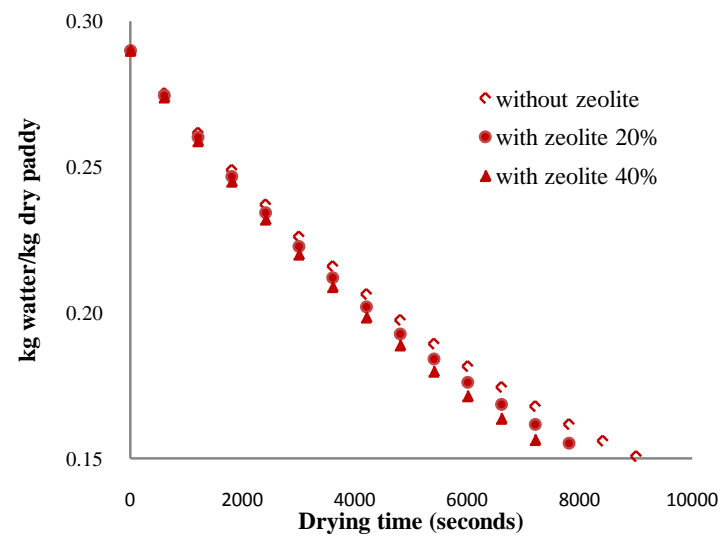

Figure 2. The response of moisture content versus time in the paddy drying with zeolite 20 and $40 \%$, and without zeolite at operational temperature $50^{\circ} \mathrm{C}$ and air velocity $4 \mathrm{~m} . \mathrm{s}^{-1}$

When the percentage of zeolite increased, the moisture content in the paddy decreased quickly (see Figure 2). It means that the increase of zeolite improves the air dehumidification in which enhances the driving force for drying. Here, paddy drying with zeolite can speed up drying time $5-10 \%$ faster than the drying without zeolite. The result is in line with the previous data cited from other application of zeolite in dryer where the drying with zeolite gives the positive effect both in drying rate as well as product quality (Ratti, 2001; Nagaya et al., 2006).

\section{The Effect of Operational Temperature}

In this experiment, the operational temperature of paddy drying with zeolite $40 \%$ in the dryer was varied in the range of $40-60^{\circ} \mathrm{C}$. The response of moisture content in paddy versus time was illustrated in Figure 3.

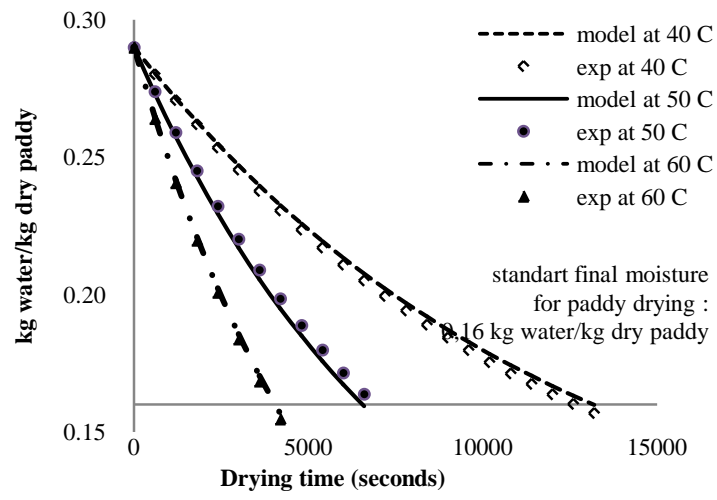

Figure 3. The response of moisture content in paddy versus time at different operational temperature for zeolite $40 \%$ and air velocity $4 \mathrm{~m} . \mathrm{s}^{-1}$
The result showed that the higher temperature, higher drying rate. At higher temperature, the air has more sensible heat that can be used for evaporating water. In addition, at higher temperature, the relative humidity of air is low. So, the capacity of air to bring vapor increases.

The water diffusivity and constant of drying rate were predicted using equation 1-4 and the physical properties of air cited from previous publication (Djaeni et al., 2012). Firstly, the moisture diffusivity in paddy was estimated using Equation 12. After that, the constant of drying rate is calculated with Equation 3-4.The results were depicted in Table 1.

Table 1. The value of water diffusivity, Sherwood number, and mass transfer coefficient in various operational air temperature

\begin{tabular}{cccc}
\hline $\begin{array}{c}\text { Temperature } \\
\left({ }^{\mathrm{O}}\right)\end{array}$ & $\begin{array}{c}\text { Diffusivity } \\
\mathrm{x} 10^{-11} \mathrm{~m}^{2} . \mathrm{s}^{-1}\end{array}$ & $\begin{array}{c}\text { Sh } \\
\text { number }\end{array}$ & $\begin{array}{c}\mathrm{k} \\
\mathrm{x} 10^{-4} \mathrm{~s}^{-1}\end{array}$ \\
\hline 40 & 0.47 & 5756 & 0.86 \\
50 & 0.79 & 4802 & 1.21 \\
60 & 1.4 & 3939 & 1.76 \\
\hline
\end{tabular}

Regarding to the Table 1, at higher temperature, the diffusivity of moisture in paddy tissue was higher. Thus, higher drying rate was also obtained. In doing so, the diffusivity and constant of drying rate was also validated with experimental data at same operational condition. The result showed that the estimated moisture content versus time fits to the experimental result (see Figure 3). In this study, the moisture diffusivity was obtained in the range of $10^{-12}$ $-10^{-11} \mathrm{~m}^{2} \cdot \mathrm{s}^{-1}$. The result is still comparable with the estimation performed in Parkash (2011) and Golmohammadi et al. (2012).

\section{The Effect of Air Dehumidification}

The temperature and relative humidity affects the equilibrium moisture in paddy as expressed by GAB model (see Equation 2). Higher temperature decreases the water loaded in paddy. In contrast, higher relative humidity results higher moisture loaded (see Figure 4).

For paddy drying, the moisture content in the final process is set at $12-14 \%$ (wet basis) or about $0.13-0.15 \mathrm{~kg}$ water $/ \mathrm{kg}$ dry paddy. It can be gained by reducing relative humidity, increasing air temperature, or combination of these factors. In this case, by considering the heat effect on paddy quality, the reducing air relative humidity is preferable (see Figure 4).

The drying time of paddy was estimated for various temperature and relative humidity using Equation 3-6. The constant of drying rate was obtained by linear extrapolation of $k$ depicted in Table 1. Results were presented in Figure 5. 


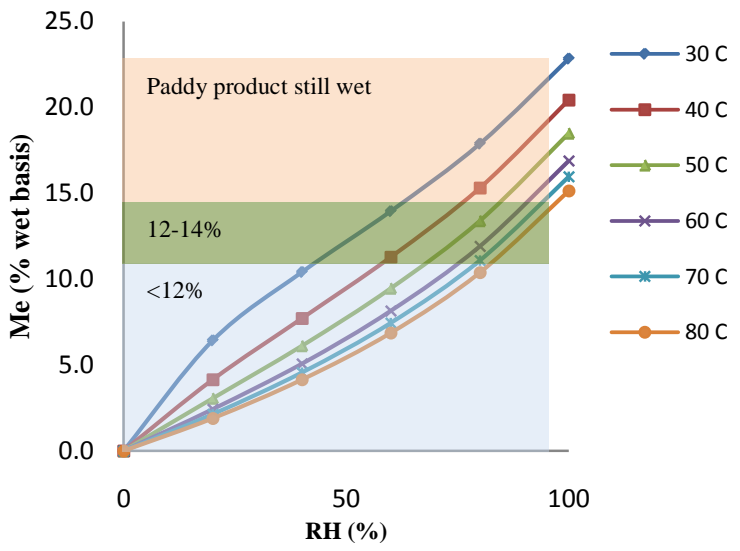

Figure 4. The equilibrium moisture content in paddy at various temperatures and relative humidity

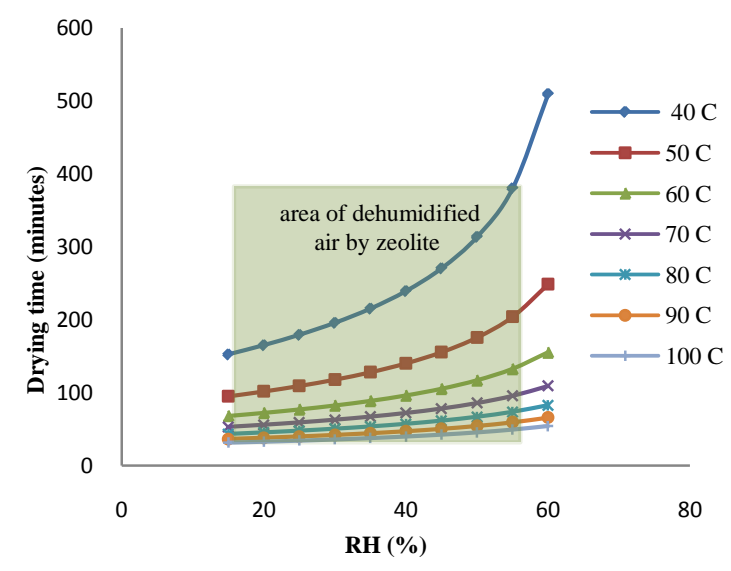

Figure 5. The drying time for paddy at various temperatures and relative humidity for air velocity $4 \mathrm{~m} . \mathrm{s}^{-1}$

For all cases, the lower relative humidity shortens the drying time (see Figure 5). This improvement is more significant compared to the other methods published by Taweerarattanapanish et al. (1999), Witinantakit et al. (2006) and Soponronnarit (1999). For example without air dehumidification, the drying time of paddy from 33 to $16 \%$ (wet basis) requires 53 minutes at $150^{\circ} \mathrm{C}$ (Soponronnarit, 1999). This result is comparable with paddy drying with zeolite at operational temperature $60-70^{\circ} \mathrm{C}$ and relative humidity below $20 \%$. This achievement is very meaningful, since the quality of paddy can be well retained.

The effect of air dehumidification is more significant at operational temperature below $80^{\circ} \mathrm{C}$ (see Figure 5). For example, at operational temperature $40^{\circ} \mathrm{C}$, the drying time can be shortened up to 300 minutes by reducing the relative humidity from $60 \%$ to $20 \%$. At temperature $50^{\circ} \mathrm{C}$, with the same relative humidity reduction, the drying can be speed up about 100 minutes. Meanwhile, at $80^{\circ} \mathrm{C}$ or higher, the air dehumidification can give slightly impact only.

\section{The Effect of Air Velocity}

The drying time at various air velocity and relative humidity were estimated using Equation 5-6. Firstly, the values of drying rate constant were predicted using Equation 3-4 by variation of air velocity. The results were depicted in Table 2 . With the values, the drying time was then estimated as illustrated in Figure 6.

Table 2. The value of water diffusivity,

Sherwood number, and mass transfer coefficient in operational temperature $50^{\circ} \mathrm{C}$

\begin{tabular}{|c|c|c|c|}
\hline $\begin{array}{c}\text { Air Velocity } \\
\left(\mathrm{m}^{\left.-\mathrm{s}^{-1}\right)}\right.\end{array}$ & $\begin{array}{l}\text { Diffusivity } \\
\mathrm{x} 10^{-11} \mathrm{~m}^{2} . \mathrm{s}^{-1}\end{array}$ & $\begin{array}{c}\text { Sh } \\
\text { number }\end{array}$ & $\begin{array}{c}\mathrm{k} \\
\mathrm{x} 10^{-4} \mathrm{~s}^{-1}\end{array}$ \\
\hline 3 & 0.79 & 4159,104 & 1.05 \\
\hline 4 & 0.79 & 4802,210 & 1.21 \\
\hline 5 & 0.79 & 5368,798 & 1.35 \\
\hline
\end{tabular}

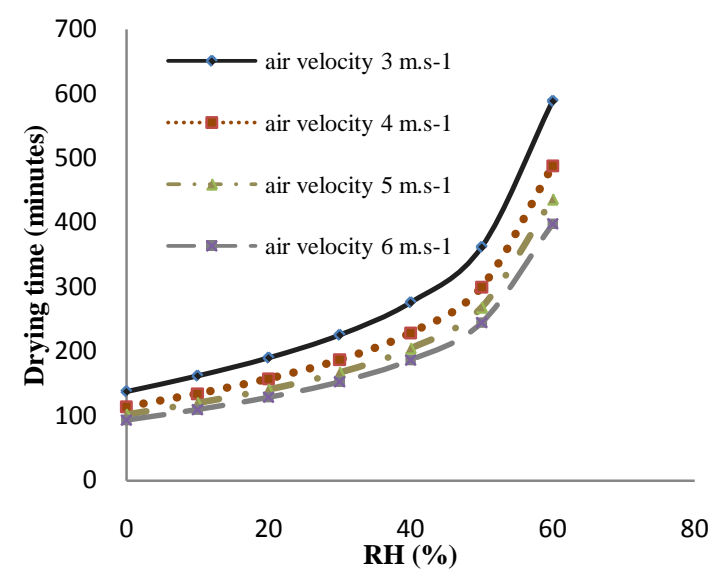

Figure 6 . The drying time for paddy at various air velocity and relative humidity for temperature $50^{\circ} \mathrm{C}$.

The increase of air velocity enhances the Sherwood number in which makes the constant of drying rate being higher. As a result, the drying was shorter as presented in Figure 6. Meanwhile, the lower relative humidity also reduces the drying time. Hence, it can be noted that for heat sensitive products such as paddy, the increase of air velocity can be a potential option to speed up drying time instead of increasing operational temperature. This notification can also accommodate the previous recommendation pointed by Wiset et al. (2001) and Djaeni et al. (2009).

\section{CONCLUSION}

The comparison of drying paddy with and without zeolite has been done both in experiment and model. The model was validated and used for calculating drying time at extrapolated condition. Results showed that the zeolite can improve the driving force for drying as indicated in shorter drying time as well as higher drying rate.

The effect of zeolite for air dehumidification is very significant at operational drying temperature below $80^{\circ} \mathrm{C}$. Upper $80^{\circ} \mathrm{C}$, the relative humidity of ambient air as drying medium closes to zero. By GAB equation, the moisture loaded in paddy at 
equilibrium is very low. Hence, the zeolite or other adsorbents for air dehumidification is not needed anymore.

However, higher operational temperature degrades the quality of the paddy. So, this condition must be avoided. In this study, there are three ways to improve the drying rate as well as reduce drying time: by air dehumidification with zeolite, increase air velocity, or combination of these aspects.

\section{ACKNOWLEDGEMENT}

This research was conducted in Laboratory of Process Engineering Department of Chemical Engineering Faculty of Engineering, Diponegoro University. The zeolite 3A was provided by Zeochem, Switzerland. The research was funded by KKP3N 2013, Research and Development Institution, Ministry of Agriculture, Indonesia.

\section{REFERENCES}

Alikhan, Z., Raghavan, G.S.V., and Mujumdar, A.S., (1992), Adsorption drying of corn in zeolite granules using a rotary drum, Drying Technology, 10(3), pp. 783-797.

Barber, S., (1972), Milled rice and changes during aging, Rice: Chemistry and Technology (D.F. Houston, ed.), American Association of Cereal Chemists, St. Paul, MN, pp. 215.

Chrastil, J,. (1994), Effect of storage on the physicochemical properties and quality factors of rice. In Marshall, W.E. and Wadsworth, J.I. (Eds.), Rice Science and Technology, Marcel Dekker, Inc., New York.

Djaeni, M, (2008), Energy efficient multistage zeolite drying for heat sensitive products, Phd Thesis, Wageningen University, Netherland, ISBN:978-908585-209-4.

Djaeni, M., Bartels, P.V., van Asselt, C.J., Sanders, J.P.M., van Straten, G., and van Boxtel, A.J.B., (2009), Assessment of a Two-Stage Zeolite Dryer For Energy Efficient, Drying Technology, 27, pp. 1205 1216, DOI: 10.1080/07373930903263210

Djaeni, M., Sasongko, S.B., Prasetyaningrum, A., Jin, X., and van Boxtel, A.J.B., (2012), Carrageenan drying with dehumidified air: drying characteristics and product quality, International Journal of Food Engineering, 8(3), Article 32, DOI: 10.1515/15563758.2682

FAO, (2002), Food energy - methods of analysis and conversion factors, Report of a Technical Workshop, Rome, 3-6 December 2002, (http://www.fao.org accessed 22 ${ }^{\text {nd }}$ April 2012)

Golmohammadi, M., Rajabi-hamane, M., and Hashemi, S.J., (2012), Optimization of drying- tempering periods in a paddy rice dryer, Drying Technology 30(1), pp. 106-113, DOI:10.1080/07373937.2011.618281

Iguaz, A. and Virseda, P., (2011), Moisture desorption isotherms of rough rice at high temperatures, in Advanced Topics in Mass Transfer, El-Amin, M. ISBN : 978-953-307-333-0 (http://www.intechopen.com/accessed $18^{\text {th }}$ January 2013)

Kiranoudis, C.T., Maroulis Z.B., and MarinosKouris, D., (1996), Drying of solids: Selection of some continuous operation dryer types, Computer \& Chem. Eng., 20, Supplement 1, pp. S177-182.

Nagaya, K., Li, Y., Jin, Z., Fukumuro, M., Ando, Y., and Akaishi, A., (2006), Low-temperature desiccantbased food drying system with air flow and temperature control, Journal of Food Engineering, 75 , pp. $71-77$.

Prakash, B., (2011), Mathematical Modeling of Moisture Movement within a Rice Kernel during Convective and Infrared Drying, Dissertation of Doctor of Philosophy in Biological System Engineering in the Office of Graduate Studies of the University of California Davis, USA.

Ratti, C., (2001), Hot air and freeze-drying of highvalue foods: a review, Journal of Food Engineering, 49, pp. 311-319.

Revilla, G.O., Velázquez, T.G., Cortés, S.L., and Cárdenas, S.A., (2006), Immersion drying of wheat using Al-PILC, zeolite, clay, and sand as particulate media, Drying Technology, 24(8), pp. 1033-1038.

Soponronnarit, S., (1999), Fluidized-bed paddy drying, Science Asia, pp. 51-56 (http://www.scienceasia.org/accessed $22^{\text {nd }}$ January 2013)

Taweerarattanapanish, A., Soponronnarit, S., Wetchakama, S., Kongseri, N., and Wongpiyachon, S., (1999, Effects of drying on head rice yield using fluidization technique, Drying Technology, 17(2), pp. 346-353, DOI:10.1080/07373939908917535

Wiset, L., Srzednicki, G., Driscoll, R., Nimmuntavin, C., and Siwapornrak, P., (2001), Effects of high temperature Drying on rice quality, Agricultural Engineering International, the CIGR Journal of Scientific Research and Development, Manuscript FP 01 003, Vol. III.

Witinantakit, K., Prachayawarakom, S., Nathakaranakule, A., and Soponronnarit, S., (2006), Paddy drying using adsorption technique: Experiments and simulation, Drying Technology, 24 (5); pp. 609-617, DOI:10.1080/07373930600626503. 